\title{
Abundance of Three Sap Sucking Pests on Three Eggplant Cultivars With Utilization of Phytoseiulus persimilis Athias-Henriot against Tetranychus urticae Koch
}

\author{
Aziza M. M. Abou-Zaid"; E. M. Bakr*; Samia A. Yassin ${ }^{\star}$ and Neama A Abdel Hameed ${ }^{\star *}$ \\ "Plant Protect. Res.Institute, (ARC). Dokki, Giza.Egypt. \\ ** Zoology Dept., Faculty of Science (Girls), Al-Azhar University.
}

\begin{abstract}
Abundance and fluctuation of Tetranychus urticae Koch, Aphis gossypii Glover and Bemisia tabaci (Gann.) were studied on three eggplant cultivars (i.e. Baladi-White, Florida Market and Baladi-Black) during 2009 and 2010 successive seasons. T. urticae occurrence continued almost all the season and reached its maximum at the end of June or the beginning of July. A gossypii reaching the highest abundance in the middle of September while $B$. tabaci reached its maximum abundance at the end of July and first half of August. Variance in susceptibility among tested cultivars was recorded based on the abundance averages overall the two seasons. Florida Market, Baladi-White and Baladi-Black recorded the lowest abundance of $T$. urticae, $A$ gossypii and $B$. tabaci, respectively. Phytoseiulus persimilis proved to be a good biocontrol agent against $T$. urticae at release ratios of 1:5 and 1:10 predator : prey. A reduction appeared one week after release, generally it revealed 68.60 and $88.20 \%$ mean reduction for both release ratios, respectively.
\end{abstract}

Key Words: Eggplant, Tetranychus urticae, Bemisia tabaci, Aphis gossypii, Phytoseiulus persimilis, Abundance and Biological control.

\section{INTRODUCTION}

Eggplant, Solanum melongen L, is one of the important solanaceous plants. Its production is highly concentrated. Ninty percent of production comes from five countries, China produes 24.5 melion tons followed by India 10.6 and Egypt come the third by 1.2 melion tons per year. About 1.7 million hectares are devoted to cultivate eggplant in the world (FAOSTAT 2010, http://faostat.f ao.org/site/567/DesktopDefault.aspx). Eggplant grow in temperate climates, so it is subjected to many pests as the two spotted spider mite, Tetranychus urticae Koch, the whitefly Bemisia tabaci (Gann.) and Aphis gosspii Glover. These pests cause great damage to the plant. $T$. urticae feeds on the plant sap causing serious damage varying according to the degree of infestations (Iskander et al., 2002). The primary damage caused by aphids and whiteflies is the production of sticky honeydew and subsequent growth of black sooty mold on the honeydew, lowering the photosynthetic capacity of the plant and making the fruit unattractive. They can also stunt plants by feeding early in the season before blooming.

Studying pests fluctuation along the season should help to define the proper control timing which result in reduce the use of pesticides and avoid any misplacement of predator. Screening of susceptibility of different cultivars against pests may help in I.P.M. strategies. It also may help in the breeding of resistant varieties.

Using predaceous mites is considered the safest methods in controlling mite pest attacking the field crops especially the two-spotted spider mite on eggplant cultivars.

The present work was conducted throughout two successive summer seasons 2009 and 2010, to study the fluctuation of $T$. urticae, $A$ gossypii and $B$. tabaci along the planting season, in Egypt, to shade some light on the relative susceptibility of the three eggplant cultivars to infestation with the same pests under field conditions. The efficiency of the predatory mite, Phytoseiulus persimilis AthiasHenriot in two different releasing ratios of predator: pest $(1: 5 \& 1: 10)$ against $T$. urticae throughout twelve weeks after release was considered.

\section{MATERIALS AND METHODS}

\section{Abundance of sap sucking pests on different eggplant cultivars:}

The abundance of $T$. urticae, B. tabaci and $A$ gossypii on the eggplant cultivars (i.e. Baladi-white, Florida Market and Baladi-Black) was studied. An area of $525 \mathrm{~m}^{2}$ was cultivated at Kaha Agricultural Research Station, Qalyubiya Governorate, Egypt during two successive seasons 2009 and 2010. The nurseries of the cultivars were transported to hills in the permanent area on $21^{\text {st }}$ of March during the two seasons. The experimental area was divided into 9 plots. Each tested cultivar was represented by three replicates $\left(58 \mathrm{~m}^{2}\right)$ which were arranged in a randomized complete block design.

All the recommended agricultural practices were carried out as needed. The experimental area was kept free from any pesticide treatments, as the plants were left to the natural infestation. 
Three weeks after transplantation from the nurseries and for 29 weeks later, samples of ten leaves representing all plant levels were weekly picked from each replicate (30 leaves for each cultivar). The collected leaves were placed directly into paper bags and taken to the laboratory. All stages of $T$. urticae, $A$ gossypii and the imature stages of $B$. tabaci were counted using stereomicroscope.

\section{Biological control:}

The predatory mite $P$. persimilis was utilized as a biological control agent against $T$. urticae on eggplant. The predatory mite was reared on kidney been plants, Phaseolus vulgaris (L.) which previously infested with $T$. urticae. Kidney been plants were planted in plastic pots and placed in isolated greenhouse covered with a fine mesh plastic net $\left(500\right.$ holes $\left./ \mathrm{inch}^{2}\right)$. The predator culture was monitored daily and provided with prey when needed, until the populations of the predator became suitable for harvest.

Releasing the predatory mite was carried out in separate area on Florida Market cultivar as the population of T. urticae built up on $16^{\text {th }}$ May 2009. The predator was released with two ratios 1:5 and 1:10 predator: prey, respectively. The experimental area was di rided into 9 plots which was arranged in a randomized complete block design. Each rate was represented by 3 replicate, besides three plots as control. Bean leaves with the predatory mite were transferred in an ice-box to eggplant field and then distributed on infested eggplant plants in order to achieve required release ratio. A sample of thirty eggplant leaves were picked up to the laboratory in order to count the motile stages of $T$. urticae once before release, and then weekly for the thirteen subsequent weeks.

\section{Statistical analysis:}

Data were subjected to analysis of variance (ANOVA) using SAS program (SAS Institute, 1988) and means were separated by LSD. For biological control experiment, percentages of reduction in the number of motile stages of $T$. urticae were calculated using the equation of Henderson and Tilton (1955).

\section{RESULTS AND DISCUSSION}

\section{Abundance of Tetranychus urticae:}

The abundance (number of mites/inch ${ }^{2}$ ) of $T$. urticae on three eggplant cultivars (i.e. BaladiWhite, Florida and Baladi-Black) was examined during the growing season that extended between April 11, to October 24, in the two successive years, 2009 and 2010 (Figs. 1 \& 2). The mite infestation started from the first week of the observation until the end of the season on all the tested cultivars. The population fluctuated all over the examining period. The first peak was moderate and reached its maximum after the mid of April then decreased. The abundance started to raise up once again in the middle of May and reached the highest peak in the end of June or the beginning of July as it reached almost 80 mites/ inch $^{2}$ in Baladi-White cultivar. Another smaller peak was recorded before or at the mid of August. Then the population of the mite decreased in the subsequent month September. After that one moderate peak was observed, at the first third of October. Relative susceptibility of three eggplant cultivars to the $T$. urticae was calculated on bases of the abundance averages on the three cultivars along the two seasons and tabulated in Table (1). Baladi-white cultivar hosted the highest population followed by Baladi-Black and Florida Market. Averages of abundance in 2009 season were $32.96,32.59$ and $25.81 \mathrm{mite} / \mathrm{inch}^{2}$, respectively. Averages of abundance showed the same trend in 2010 season with averages of 28.96, 18.14 and 14.28 mite/inch ${ }^{2}$, respectively. According to calculated LSD, Florida Market cultivar significantly hosted the least mite population in the two seasons.

\section{Abundance of Aphis gossypii:}

Considering the population fluctuation of A. gossypi on the three eggplant cultivars, Figures (3 \& 4) illustrate the abundance of the aphid infestation during 2009 and 2010 seasons. A little or moderate abundance was recorded at the end of April and the beginning of May. Then the aphid abundance decreased to reach its minimum in June. Then aphid population started to increase gradually in the beginning of July until it reached the highest abundance in the middle of September then decreased again. As shown in Table (1), according to abundance averages, Baladi-White cultivar hosted the least aphid population among the tested cultivars in the two seasons. Whereas aphid density on this cultivar was significantly lower in 2009 season only.

\section{Abundance of Bemisia tabaci:}

The population curve of $B$. tabaci on the three tested cultivars (Figures 5 \& 6) showed almost the same trend during the two studied seasons. The population started very low and increased gradually at the beginning of May to form a peak at the middle of June then it breaked down at the end of this month. B. tabaci started to increase once again in the first half of July as it reached the maximum abundance during the end of July and first half of August. Then the abundance decreased gradually through the last two months, September and 


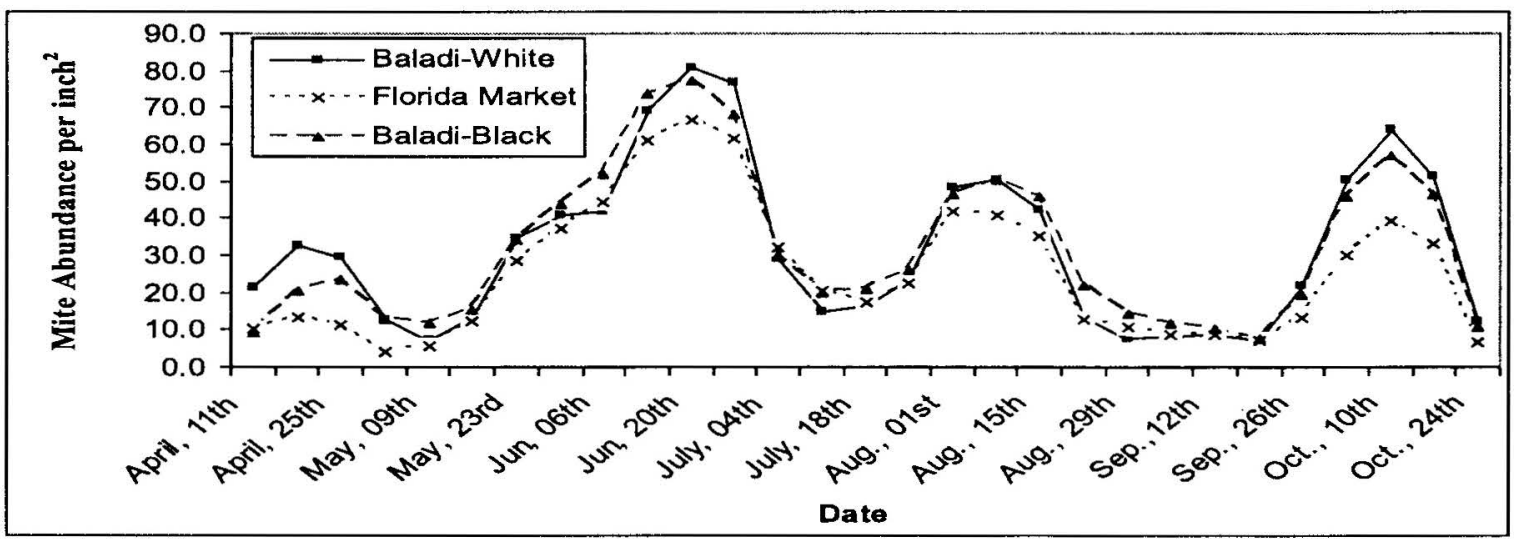

Fig. (1): Fluctuation of T. urticae population density on three eggplant cultivars in 2009.

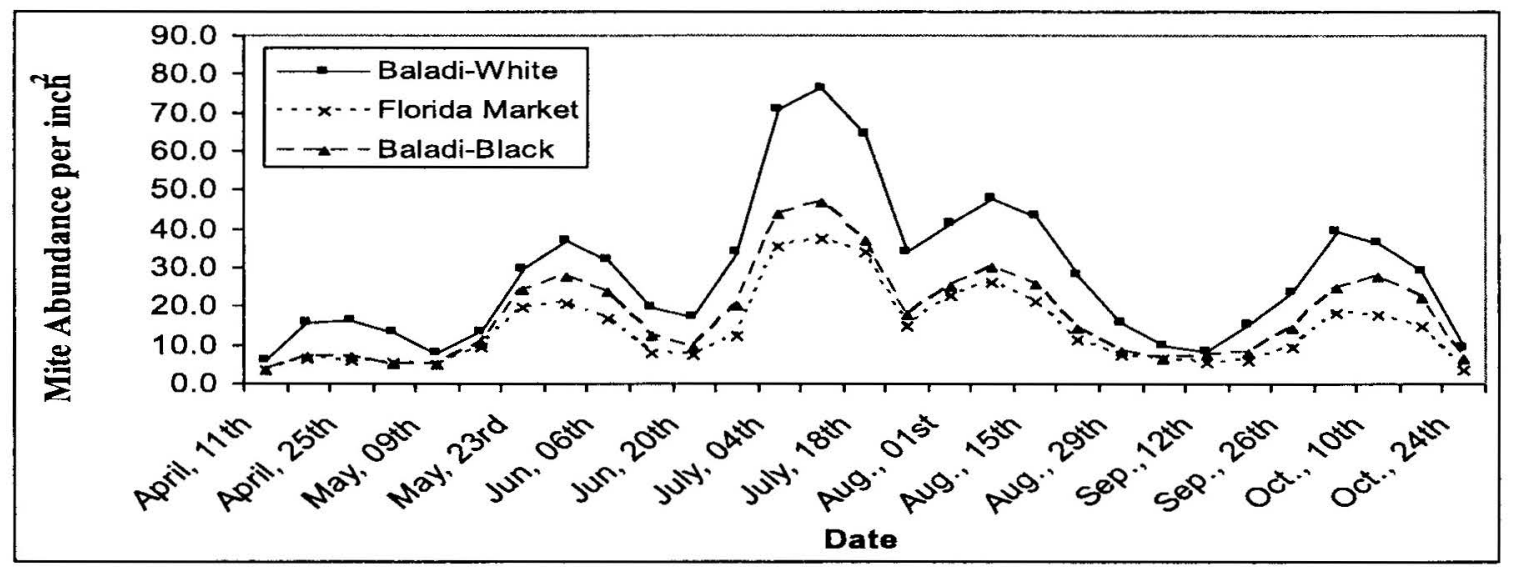

Fig. (2): Fluctuation of T. urticae population density on three eggplant cultivars in 2010.

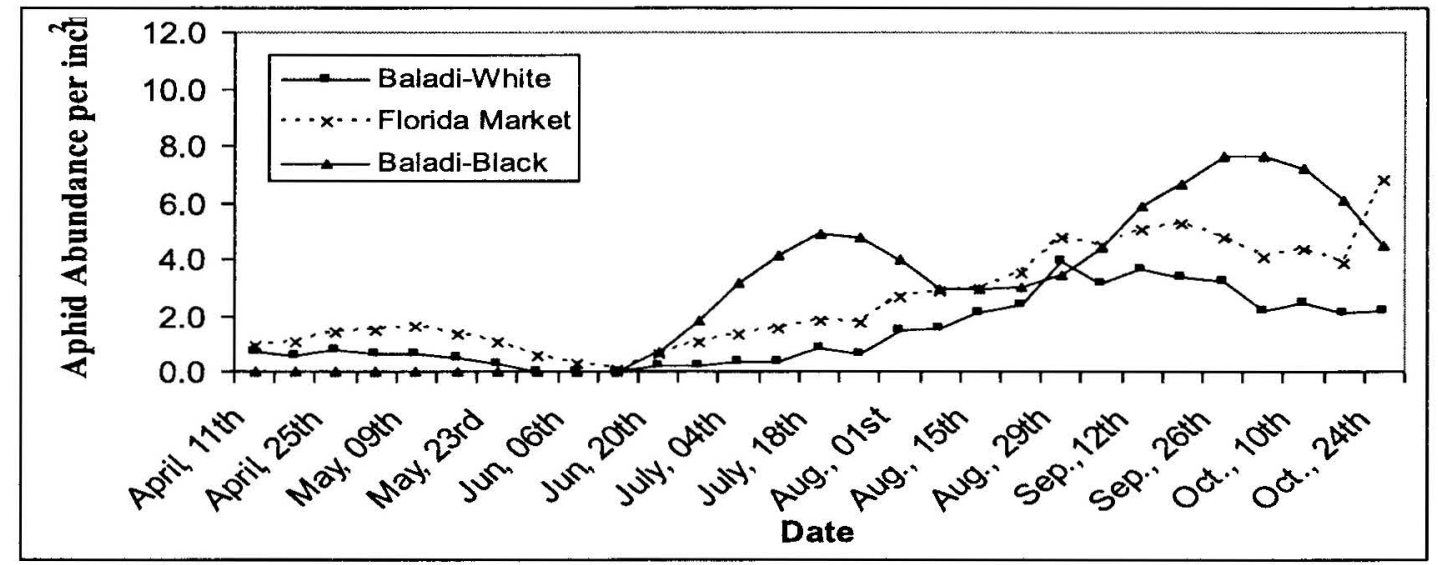

Fig. (3): Fluctuation of $A$ gossypi population density on three eggplant cultivars in 2009.

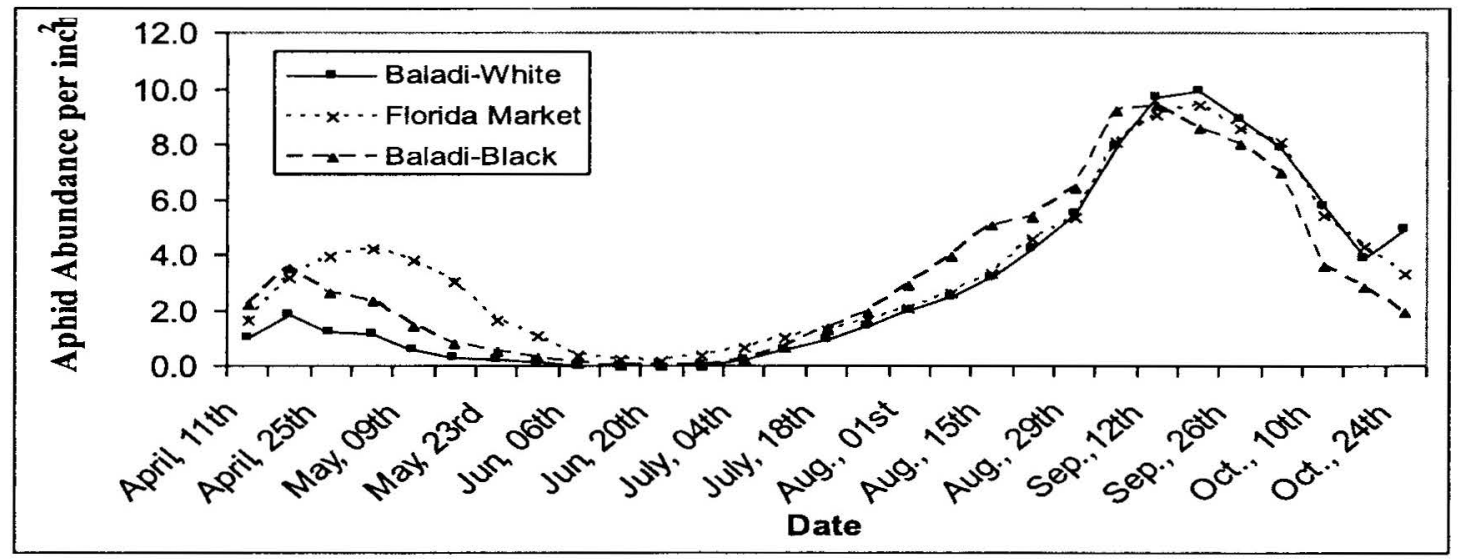

Fig. (4): Fluctuation of $A$ gossypi population density on three eggplant cultivars in 2010 . 


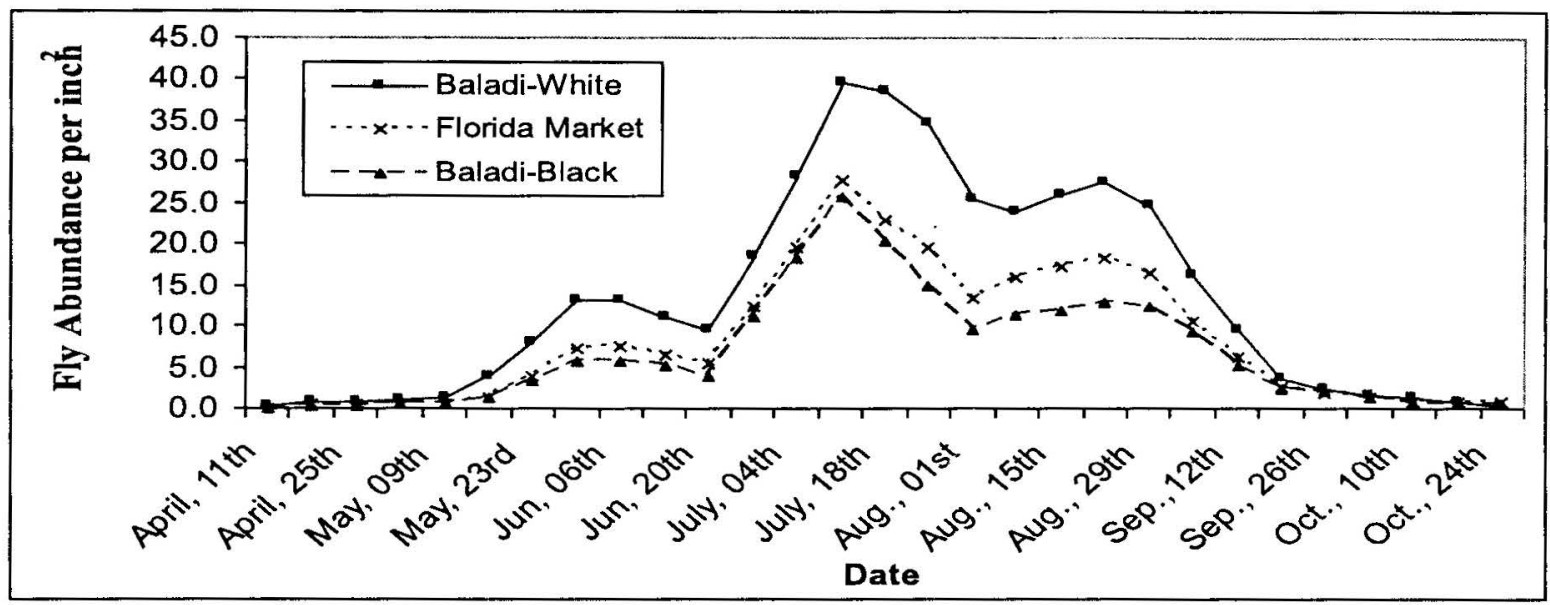

Fig. (5): Fluctuation of B. tabaci population density on three eggplant cultivars in 2009.

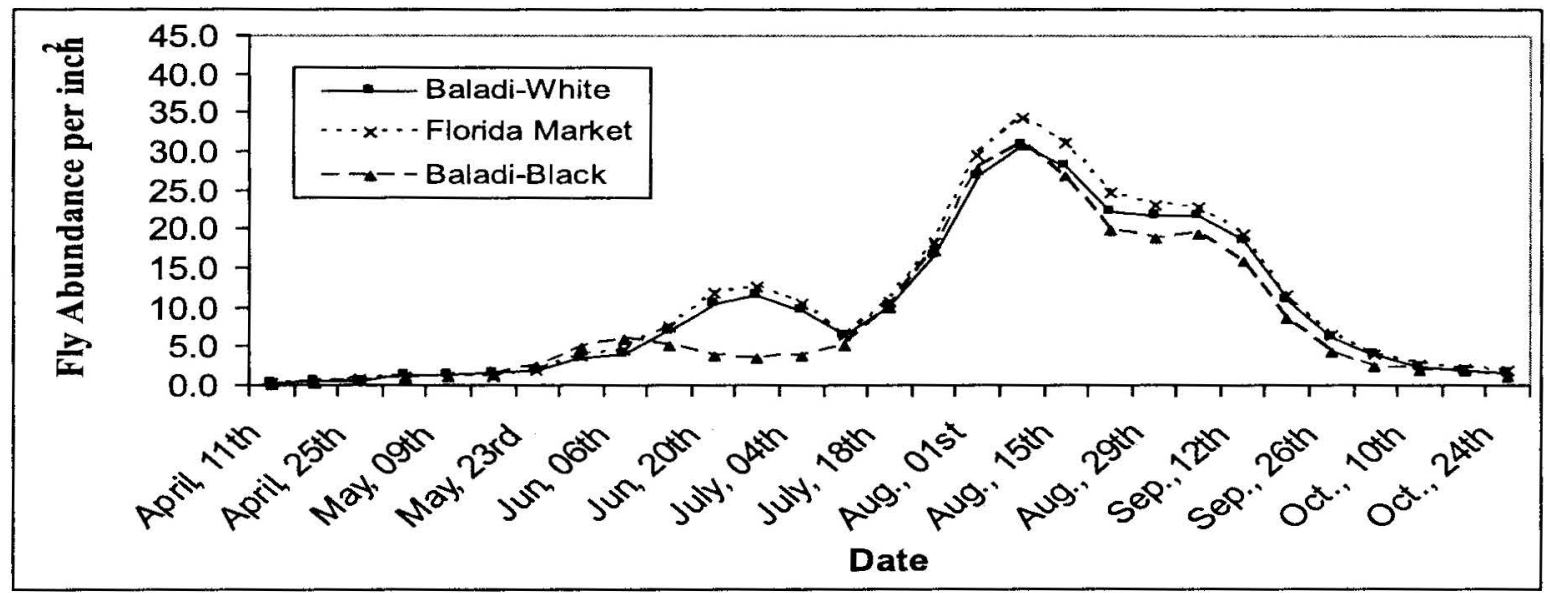

Fig. (6): Fluctuation of $B$. tabaci population density on three eggplant cultivars in 2010.

October. Data in Table (1) revealed that, BaladiBlack was the lowest preferable cultivar for $B$. tabaci as it demonstrated the lowest abundance compared with the other two cultivars.

Differences in population increase and degree of infestations of the pests on different eggplant varieties or cultivars were demonstrated in various studies among them Parvane et al., (2002) on nine commercial egg-plant varieties and Islam et al., (2010) on 3 eggplant varieties. Iskandar (2003) mentioned that Florida Market was one of the least infested varieties with $T$. urticae.

Table (1): Abundance averages of three sucking pests on three eggplant cultivars

\begin{tabular}{clccc}
\hline year & \multicolumn{1}{c}{ Cultivar } & $\begin{array}{c}T \\
\text { urticae }\end{array}$ & $\begin{array}{c}A \\
\text { gossypii }\end{array}$ & $\begin{array}{c}B \\
\text { tabaci }\end{array}$ \\
\hline \multirow{2}{*}{$\underset{\delta}{ }$} & Baladi-White & $32.96 \mathrm{a}$ & $1.40 \mathrm{~b}$ & $13.28 \mathrm{a}$ \\
\cline { 2 - 5 } & Florida Market & $25.81 \mathrm{~b}$ & $2.50 \mathrm{a}$ & $8.34 \mathrm{~b}$ \\
\cline { 2 - 5 } & Baladi-Black & $32.59 \mathrm{a}$ & $3.01 \mathrm{a}$ & $6.78 \mathrm{~b}$ \\
\cline { 2 - 5 } & LSD & 4.19 & 0.94 & 1.92 \\
\hline \multirow{2}{*}{} & Baladi-White & $28.96 \mathrm{a}$ & $2.93 \mathrm{a}$ & $9.77 \mathrm{a}$ \\
\cline { 2 - 5 } & Florida Market & $14.28 \mathrm{c}$ & $3.58 \mathrm{a}$ & $10.55 \mathrm{a}$ \\
\cline { 2 - 5 } & Baladi-Black & $18.14 \mathrm{~b}$ & $3.19 \mathrm{a}$ & $8.41 \mathrm{~b}$ \\
\cline { 2 - 5 } & LSD & 3.47 & 0.67 & 1.07 \\
\hline
\end{tabular}

Biological control of $T$. urticae on eggplant with the predatory mite, Phytoseiulus persimilis:

As it is tabulated in Table 2 , both released ratios $(1: 5,1: 10)$ revealed a reduction of 42.11 and $38.56 \%$, respectively, one week after release. Then, the reduction percent of the pest increased gradually by time until reaching the maximum at $6^{\text {th }}-9^{\text {th }}$ week after release. Then the percent reduction fluctuated until the end of the season during the thirteen weeks of evaluation.

Regarding the mean reduction for the two levels of treatments, it was observed that the mean percentages were 68.60 and 88.20 for the levels 1:5, and 1:10 predator: prey, respectively. These data proved that $P$. persimilis release at level 1:10 gave better results for biocontroling $T$. urticae on eggplant. So it could be recommended to use $P$. persimilis to control $T$. urticae on eggplant.

Biocontrol of $P$. persimilis against $T$. urticae was proved on many hosts by several authors but on eggplant by El-Saiedy et al., (2008); Shibao and Tanaka (2006)). 
Table (2): The mean density of $T$. urticae mobile stages before and after releasing $P$. persimilis on eggplant plant with the corresponding reduction percentage

\begin{tabular}{|c|c|c|c|c|c|}
\hline \multirow{2}{*}{$\begin{array}{l}\text { Releasing level } \\
\text { Sampling date } \\
\end{array}$} & \multicolumn{2}{|c|}{$\begin{array}{c}1: 5 \\
\text { predator : prey }\end{array}$} & \multicolumn{2}{|c|}{$\begin{array}{c}1: 10 \\
\text { predator: prey }\end{array}$} & \multirow[t]{2}{*}{ Contro } \\
\hline & Mean & R.\% & Mean & R.\% & \\
\hline Pre count & 9.00 & & 10.50 & & 8.90 \\
\hline After $1^{\text {st }}$ week & 9.60 & 42.11 & 11.90 & 38.50 & 16.40 \\
\hline $2^{\text {nd }}$ week & 11.80 & 65.78 & 13.10 & 67.44 & 34.10 \\
\hline $3^{\text {rd }}$ week & 14.20 & 72.03 & 16.10 & 72.82 & 50.20 \\
\hline $4^{\text {th }}$ week & 13.60 & 75.94 & 5.70 & 91.36 & 55.90 \\
\hline $5^{\text {th }}$ week & 3.20 & 95.52 & 2.10 & 97.48 & 70.70 \\
\hline $6^{\text {th }}$ week & 0.00 & 100.00 & 0.50 & 99.58 & 100.30 \\
\hline $7^{\text {th }}$ week & 0.00 & 100.00 & 0.00 & 100.00 & 105.40 \\
\hline $8^{\text {th }}$ week & 0.05 & 99.94 & 0.00 & 100.00 & 76.40 \\
\hline $9^{\text {th }}$ week & 11.10 & 87.15 & 0.00 & 100.00 & 85.40 \\
\hline $10^{\text {th }}$ week & 30.60 & 70.25 & 0.00 & 100.00 & 101.70 \\
\hline $11^{\text {th }}$ week & 57.50 & 51.32 & 0.10 & 99.93 & 116.80 \\
\hline $12^{\text {th }}$ week & 30.70 & 22.16 & 2.70 & 94.13 & 39.00 \\
\hline $13^{\text {th }}$ week & 17.00 & 9.62 & 3.20 & 85.42 & 18.60 \\
\hline Mean R. \% & & $68.60 \mathrm{~B}$ & & $88.20 \mathrm{~A}$ & \\
\hline
\end{tabular}

\section{REFERENCES}

El-Saiedy, E. M. A.; Abou-Elella, G. M. A. and Alotabibi, S. A., 2008. Efficiency of three predatory phytoseiid mites and biocide chemical for controlling Tetranychus urticae Koch on eggplant at Beheira Governorate. Res. J. of Agric. \& Biol. Sci., 4(3): 238-244. http://www.aensionline.com/rjabs/rjabs/2008/238 -244.pdf

Henderson, C.F. and Tilton, W.A., 1955. Test with acaricides against the wheat mite. J. Econ. Ent. 49: 157-161.

Iskander, A.K.F., 2003. Natural varietal resistance of some common eggplant, Solanum melongena L. varieties against the two spotted-spider mite, Tetranychus arabicus Attiah infestation under field conditions of Egypt. Minufia J. Agric. Res. 28 (6) : 1925-1938.

Iskander, A.K.F.; EL-khateeb, H. M. and Habashy, N. H., 2002. Relative susceptibility of some pepper varieties to the two spotted-spider mite Tetranychus arabicus Attiah infestation under natural field conditions. 2nd inter. Conf., Plant
Protic. Res. Inst. Cairo, 21-24 December. 28-32.

Islam, M. T.; Qiu, B. and Ren, S., 2010. Host preference and influence of the sweetpotato whitefly, Bemisia tabaci (Homoptera: Aleyrodidae) on eggplant (Solanum melongena L.). Acta Agriculturae Scandinavica, Section B Plant Soil Science. 60 (4): 320 - 325. http://www.tandfonline.com/doi/abs/10.1080/090 64710902976974

Parvane, B.; Pishe S. A. R.; Masoud, A.; Khadije, H. and Yadollah, E., 2002. Study on comparative resistance egg-plant varieties to web spider mites (Tetranychus spp.) on different of egg-plant varieties in Varamine region. Cited in $\mathrm{http} / /$ agris.fao.org/agris-search/search/display.do ?f $=2007 \%$ FIR\%2FIR0708.xml\%3BIR20600192.

SAS Institute, 1988. SAS / Stat user's guide, 6.03 ed. SAS institute, Cary, NC.

Shibao, M. and Tanaka, H., 2006. Control of spider mites on greenhouse eggplant [Solanum melongena] by releasing of Phytoseiulus persimilis Athias-Henriot. Bull. of Agric., Food and Enviro. Scie. Res. Center of Osaka Prefecture..42: 1-4. 